\title{
Edukasi Vaksinasi Covid-19 dan Penerapan 5M Dalam Menanggulangi Penularan Covid-19 di Desa Borisallo Kabupaten Gowa
}

\author{
${ }^{1}$ Sari Aldilawati, ${ }^{2}$ Rahmat Hidayat \\ 1,2 Universitas Muslim Indonesia \\ Korespondensi: sharyaldila@umi.ac.id
}

\begin{abstract}
The spread of Corona Virus Disease 2019 (Covid19) in Indonesia is very fast, so special actions and handling are needed. The government issued social distancing policies and PSBB (Large-Scale Social Restrictions), as well as the implementation of the Health protocol (5M) to stop the spread of Covid-19. Stopping the spread of this virus is not enough just to prevent its transmission, but also must be assisted so that people have good body immunity to combat the risk of the Covid-19 virus, for example by carrying out vaccinations. This community service is carried out as a form of the Tri Dharma of Higher Education, community service with the theme of the importance of vaccination and implementing $5 \mathrm{M}$ in preventing the transmission of covid-19 is not without reason but seeing the tendencies and habits of the people who always ignore health protocols, besides that this service is in the form of counseling. The purpose of this service is to educate the public about the impact and influence of Covid-19. The method of implementing community service with direct counseling techniques to the community. The results of the service, in general the counseling participants said that their knowledge of covid-19 was increasing and they were committed to complying with the Health protocol along with public understanding of 5M in order to prevent the spread of Covid-19 by applying it in daily life such as using masks, washing hands, keeping distance, staying away from crowds, and reducing mobility, also dare to vaccinate. The conclusion of this service is the importance of continuous education and outreach to the community regarding the effects and dangers of Covid- 19 .
\end{abstract}

\begin{abstract}
ABSTRAK
Penyebaran Corona Virus Disease 2019 (Covid19) di Indonesia berlangsung sangat cepat sehingga perlu dilakukan tindakan dan penanganan khusus. Pemerintah mengeluarkan kebijakan sosial distancing dan PSBB (Pembatasan Sosial Berskala Besar), serta penerapan protokol Kesehatan (5M) untuk memutus penyebaran Covid-19. Pemutusan penyebaran virus ini tidak cukup hanya dengan pencegahan penularannya saja tetapi juga harus dibantu agar masyarakat memiliki imunitas tubuh yang baik untuk memerangi risiko virus Covid-19, contohnya adalah melakukan Vaksinasi. Pengabdian masyarakat ini dilaksanakan sebagai wujud Tri Dharma Perguruan Tinggi, pengabdian masyarakat dengan mengangkat tema pentingnya Vaksinasi Covid serta penerapan 5M dalam mencegah penularan covid-19 bukanlah tanpa alasan tetapi melihat kecendrungan dan kebiasaan masyarakat yang selalu mengabaikan protokol Kesehatan, disamping itu pengabdian ini dalam bentuk penyuluhan. Tujuan pengabdian ini yakni mengedukasi masyarakat mengenai dampak dan pengaruh Covid-19. Metode pelaksanaan pengabdian dengan Teknik penyuluhan langsung kepada masyarakat. Hasil pengabdian, secara umum peserta penyuluhan mengatakan pengetahuan mereka terhadap covid-19 bertambah dan berkomitmen mematuhi protokol Kesehatan seiring dengan pemahaman masyarakat tentang 5M dalam rangka pencegahan penyebaran Covid-19 dengan menerapkannya dalam kehidupan sehari-hari seperti menggunakan masker,mencuci tangan, menjaga jarak, menjauhi kerumunan, dan mengurangi mobilitas, juga berani melakukan vaksinasi. Kesimpulan pengabdian ini yakni pentingnya edukasi dan sosialisasi secara berkesinambungan kepada masyarakat mengenai pengaruh dan bahaya Covid-19.
\end{abstract}

Kata Kunci : Covid-19, Penyuluhan, vaskinasi, Pengabdian Masyarakat

\section{PENDAHULUAN}

Pemutusan penyebaran virus ini tidak cukup hanya dengan pencegahan penularannya saja tetapi juga harus dibantu agar masyarakat memiliki imunitas tubuh yang baik untuk memerangi risiko virus Covid-19. Peningkatan imunitas tubuh bisa dengan mengonsumsi vitamin, pemanfaatan energi matahari di pagi hari dan aktivitas ringan selama beberapa menit, serta melakukan vaksinasi. Vaksin banyak sekali manfaatnya, selain untuk melindungi diri dari paparan virus, juga dapat mengurangi penyebaran virus tersebut ${ }^{1}$. 
WHO telah menetapkan Covid-19 sebagai darurat kesehatan global. Melihat situasi seperti ini, salah satu cara yang sangat memungkinkan untuk mencegah semakin luasnya penyebaran pandemi ini adalah dengan pengembangan pembuatan vaksin. Vaksin tidak hanya memberikan perlindungan bagi orang-orang yang divaksinasi, tetapi juga bagi masyarakat luas dengan mengurangi penyebaran penyakit dalam suatu populasi. Virus SARS-CoV-2 menyebar dari manusia ke manusia. Menariknya, rantai penularan dari manusia ke manusia ini dapat terputus, bahkan jika tidak ada kekebalan $100 \%$, hal tersebut disebut sebagai "herd immunity" atau "community protection", yang merupakan manfaat penting dari vaksinasi ${ }^{2,4}$.

Vaksinasi COVID-19 adalah bagian penting dari upaya penanganan pandemi COVID -19 yang menyeluruh dan terpadu meliputi aspek pencegahan dengan penerapan protocol kesehatan: menjaga jarak, mencuci tangan pakai sabun dan memakai masker (3M), vaksinasi COVID-19, dan 3T (Tes, Telusur, Tindak lanjut). Pelaksanaan vaksinasi COVID-19 bertujuan untuk memutus rantai penularan penyakit dan menghentikan wabah COVID-19. Vaksin COVID-19 bermanfaat untuk memberi perlindungan tubuh agar tidak jatuh sakit akibat COVID-19 dengan cara menimbulkan atau menstimulasi kekebalan spesifik dalam tubuh dengan pemberian vaksin.

Pelayanan vaksinasi COVID-19 dilakukan oleh dokter, perawat atau bidan yang memiliki kompetensi dan dilaksanakan di Fasilitas Pelayanan Kesehatan milik Pemerintah Pusat, Pemerintah Daerah Provinsi, Pemerintah Daerah Kabupaten/Kota atau milik masyarakat/swasta yang memenuhi persyaratan yang sudah ditentukan oleh Kementerian Kesehatan Indonesia. Saat ini, berbagai upaya edukasi penerapan protokol kesehatan terus dilakukan. Hasil studi yang dilakukan Badan Pusat Statistik dan Satuan Tugas Penanganan COVID-19 pada bulan September 2020 menunjukkan 75 persen masyarakat mencuci tangan pakai sabun, 92 persen memakai masker dan 73 persen menjaga jarak. Penerapan protokol kesehatan yang konsisten memerlukan kebijakan yang mendukung, sarana dan prasana yang memadai serta edukasi dan komunikasi perubahan perilaku yang dapat menjangkau seluruh lapisan masyarakat dengan informasi yang mudah dipahami, akurat, menarik, dan dapat mendorong terjadinya adopsi perilaku pencegahan ${ }^{5,6}$.

Langkah protokol kesehatan yang menjadi suatu kebiasaan baru di masyarakat akibat adanya pandemi adalah Gerakan 3M yaitu memakai masker, mencuci tangan dengan menggunkan sabun, dan mejaga jarak. Namun hal ini di rasa kurang, karena angka paparan covid yang terus meningkat.

Penyakit coronavirus 2019 (COVID-19) telah menyebabkan krisis kesehatan global yang berdampak besar pada cara pandang orang memahami dunia dan kehidupan sehari-hari (Frontiers, 2020). Langkah-langkah untuk pencegahan juga telah dilakukan oleh pemerintah untuk mengatasi kasus penyebaran COVID-19 seperti mensosialisasikan protokol kesehatan 5. Saat ini, masyarakat masih belum sepenuhnya mematuhi himbauan pemerintah untuk menjalankan protokol kesehatan 5M dalam pencegahan penyebaran COVID-197,8.

Gerakan 5M adalah pendukung bagi protocol kesehatan di era pandemic ini. Menjauhi kerumunan dan mengurangi mobilitas ada sebagai pelengkap bagi Gerakan 3M. Dengan menjauhi kerumunan masyarakat juga diminta untuk menjauhi kerumunan saat berada di luar rumah. Ingat, semakin banyak dan sering Anda bertemu orang, kemungkinan terinfeksi corona bisa semakin tinggi. Mengurangi Mobilitas jika tidak ada keperluan yang mendesak, tetaplah berada di rumah. Meski sehat dan tidak ada gejala penyakit, belum tentu kita dapat pulang ke rumah dengan keadaan yang masih sama. Masyarakat di edukasi untuk selalu ingat, virus corona bisa menyebar dan menginfeksi seseorang dengan cepat ${ }^{9}$.

Desa Borisallo Kabupaten Gowa merupakah salah satu Desa di Kecamatan Parangloe dengan jumlah penduduk sebanyak 3234 jiwa dengan jumlah laki-laki 1600 dan perempuan 1634. Permasalahan di bidang kesehatan pada masyarakat borisallo salah satunya adalah rendahnya minat warga tentang pentingnya vaksinasi Covid19, juga ketidaktahuan adanya Gerakan 5M sebagai pendukung dari Gerakan protokol protokol kesehatan 3M.

Dengan adanya permasalahan ini Dosen Universitas Muslim Indonesia bekerjasama dengan Mitra Pemerintah Desa Borisallo mengadakan penyuluhan kesehatan mengenai Pentingnya Vaksinasi Covid19 dan penerapan 5M untuk mencegah penularan Covid-19.

This is an open-access article under the CC BY 4.0

International License

(C) Idea Pengabdian Masyarakat (2021)

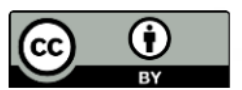

OPEN ACCESS 
Pendidikan kesehatan merupakan suatu metode mendorong dan meningkatkan pengetahuan Masyarakat sehingga menurut Notoatmojo pendidikan kesehatan melalui penyuluhan dapat mempertahankan derajat kesehatan disamping itu dapat juga mencegah datangnya penyakit. Diperlukan koordinasi sinergis dari para akademisi, tenaga kesehatan, dan pemerintah yang memiliki peran penting untuk pencegahan penyebaran Covid -19. Hal ini dikarenakan masih banyak masyarakat yang tidak peduli akan hadirnya Covid -19 itu sendiri sehingga kita harus memberikan edukasi dan mengubah pola pikir masyarakat guna untuk saling menjaga kesehatannya masing-masing. Jika pengetahuan masyarakat tentang Covid -19 sudah terpenuhi,

maka dengan sendirinya masyarakat akan mengikuti protokol kesehatan dengan baik, selalu menjaga imunitas tubuh dengan mengonsumsi vitamin dan melaksanakan vaksinasi ${ }^{10}$.

Mematuhi protokol Kesehatan adalah pilihan wajib bagi warga masyarakat ${ }^{11}$., oleh karena itu pentingnya edukasi dan sosialisasi secara berkesinambungan kepada masyarakat mengenai pengaruh dan bahaya Covid-19 $9^{12}$. berbagai pendekatan dapat dilakukan bahkan sebuah penelitian sangat merekomendasikan penerapat konsep islam dalam masyarakat ${ }^{13}$.

\section{METODE PELAKSANAAN}

Penyuluhan kesehatan ini kami bagi dalam beberapa metode pelaksanaan yakni sosialisasi, penyuluhan, penyebaran Leaflet dan poster edukasi Covid-19 yang terdiri dari 2 tahap pelaksnaan.

Tahap 1 Sosialisasi

Sosialisasi dilakukan pada pekan pertama sebelum kegiatan dilakukan yakni selasa 25 Mei 2021. sosialisasi dilakuakan bersama dengan kader Pemerintah Desa Borisallo.

Tahap II Penyuluhan Kesehatan

Tahap Penyuluhan dilakukan langsung oleh TIM pada tanggal 8 Juni 2021 dan dilakukan berdasarkan standar Kementrian kesehatan Republik Indonesia yakni sebagai Berikut:

a. Menerapkan kebiasaan mencuci tangan

b. Menerapkan kebiasaan cuci tangan pakai sabun dan air mengalir selama 40 - 60 detik atau menggunakan cairan antiseptik berbasis alkohol (handsanitizer) minimal $20-30$ detik.

c. Membiasakan penggunaan alat pelindung diri berupa masker yang menutupi hidung dan mulut jika harus keluar rumah atau berinteraksi dengan orang lain yang tidak diketahui status kesehatannya.

d. Menerapkan kebiasaan jarak minimal 1meter dengan orang lain untuk menghindari terkena droplet dari orang yang yang batuk atau bersin.

e. Membatasi diri terhadap interaksi atau kontak dengan orang lain yang tidak diketahui status kesehatannya.

f. Saat tiba di rumah setelah bepergian, segera mandi dan berganti pakaian sebelum kontak dengan anggota keluarga di rumah.

g. Meningkatkan daya tahan tubuh dengan menerapkan pola hidup bersih dan sehat (PHBS).

h. Mengelola penyakit penyerta/komorbid agar tetap terkontrol.

i. Mengelola kesehatan jiwa dan psikososial.

j. Menerapkan etika batuk dan bersin.

k. Menerapkan adaptasi kebiasaan baru dengan melaksanakan protokol kesehatan dalam setiapaktivitas.

Tahap III Pembagian Leaflet

Pembagian Leaflet dan poster dilakukan pada hari yang sama, hal ini bertujuan agar masyarakat melihat langsung melalui media yang dibagikan mengenai pentingnya vaksinasi Covid 19 dan juga 
penerapan 5M, leaflet dibagikan dengan bahasa sederhana agar masayarakat tidak kesulitan saat membaca dan memahami.

\section{HASIL DAN PEMBAHASAN}

Hasil dari kegiatan pengabdian ini adalah bertambahnya pengetahuan masyarakat tentang pencegahan Covid-19 melalui pembagian leaflet, penjelasan melalui video dan penjelasan secara langsung kepada masyarakat. Indikator keberhasilan kegiatan ini adalah warga antusias saat mendengarkan penjelasan kemudian mengajukan pertanyaan.

Penyuluhan Kesehatan

Kegiatan ini bertujuan memberikan pengetahun serta edukasi kepada Masyarakat tentang perlunya mematuhi protokol Kesehatan, pada saat akhir kegiatan Tim melakukan evaluasi dan respon masyarakat sangat Positif mengenai komitmen mereka mematuhi protokol yang dijelaskan Pemateri.

\section{Pembagian Leaflet}

Pembagian leaflet bertujuan agar Masyarakat memahami melalui media gambar tentang pentingnya vaksinasi covid 19 serta tetap mematuhi protokol Kesehatan dan menerapkan 5M dalam beraktivitas, salah satu penyebab rendahnya kesadaran masyarakat untuk mematuhi protocol Kesehatan adalah kurangnya informasi atau edukasi, media dalam hal ini harus menyebarkan langkah-langkah dan strategi pengendalian virus ini ${ }^{8}$.

Tabel 1

\begin{tabular}{|l|l|c|}
\hline No & \multicolumn{1}{|c|}{$\begin{array}{c}\text { Nama } \\
\text { Kegiatan }\end{array}$} & Ket \\
\hline $\mathbf{1}$ & $\begin{array}{l}\text { Penyuluhan Pentingnya } \\
\text { Vaksinasi Covid 19 }\end{array}$ & Terlaksana \\
\hline $\mathbf{2}$ & MM sebagai protocol kesehatan & Terlaksana \\
\hline
\end{tabular}

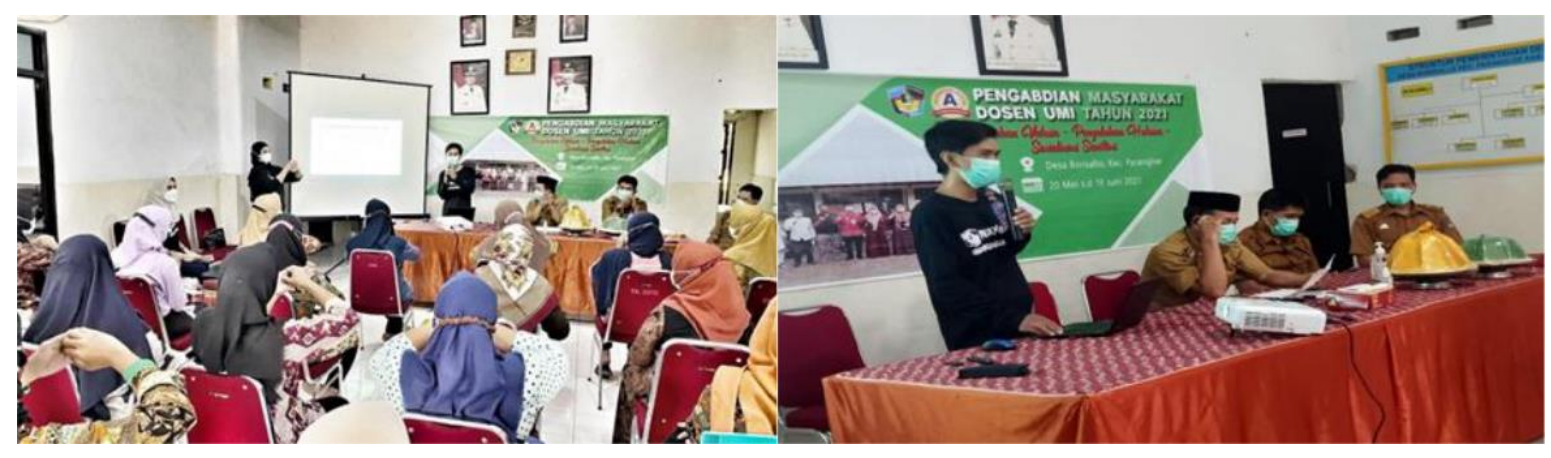

Gambar 1 dan 2 : Penyuluhan di kantor kelurahan Desa Borisallo

\section{KESIMPULAN}

Kegiatan penyuluhan kesehatan kepada masyarakat sangat penting dilakukan, mengingat kesadaran mereka akan bahaya covid-19 masih sangat kurang, pengabdian masyarakat yang dilakukan oleh Dosen adalah upaya membantu pemerintah dalam mensukseskan kebijakan serta bentuk pengimplementasian perguruan tinggi dalam melakasanakan Tri Dharma Perguruan Tinggi. 


\section{UCAPAN TERIMAKASIH}

Terimakasih Kepada Pemerintah Kabupaten Gowa, Pemerintah Desa Borisallo dan TIM Dosen serta LPkM Universitas Muslim Indonesia

\section{DAFTAR PUSTAKA}

1. Abna IM, Rahayu ST, Rizkyana M, Fauziyah D, Rohmah IT, Sholihat S. Edukasi Masyarakat Tentang Pentingnya Penerapan Protokol Kesehatan Dan Menjaga Imunitas Tubuh Dalam Rangka Pencegahan Corona Virus Disease (Covid-19) Di Desa Pesing Koneng Kedoya Utara Jakarta Barat. Pengabdi Kpd Masy. 2021;01(02):165-72.

2. Pang J, Wang MX, Ang IYH, Tan SHX, Lewis RF, Chen JI-P, et al. Potential Rapid Diagnostics, Vaccine and Therapeutics for 2019 Novel Coronavirus (2019-nCoV): A Systematic Review. J Clin Med. 2020;9(3):623. Available from: https://doi.org/10.3390/jcm9030623

3. Liu C, Zhou Q, Li Y, Garner L V., Watkins SP, Carter L, et al. Research and Development on Therapeutic Agents and Vaccines for COVID-19 and Related Human Coronavirus Diseases. ACS Cent Sci. 2020;6(3):315-31. Available from: https://dx.doi.org/10.1021/acscentsci.0c00272

4. Orensteina WA, Ahmedb R. Simply put: Vaccination saves lives. Proc Natl Acad Sci U S A. 2017;114(16):4031-3. Available from: https://doi.org/10.1073/pnas.1704507114

5. Kemenkes R. Vaksinasi Covid-19 Lindungi Diri, Lindungi Negeri. Kementeri Kesehat RI. 2021;9:22-50.

6. Kominfo. Vaksinasi COVID-19. 2020. Available from: https://pedulilindungi.id

7. Frontiers. Coronavirus Disease (COVID-19): The Impact and Role of Mass Media During the Pandemic. 2020. Available from: https://www.frontiersin.org/research-topics/13638/coronavirusdisease-covid-19-the-impact-and-role-of-mass-media-during-the-pandemic\#articles

8. Buana RD. Analisis Perilaku Masyarakat Indonesia dalam Menghadapi Pandemi Covid-19 dan Kiat Menjaga Kesejahteraan Jiwa. Sos dan Budaya, Fak Syariah dan Huk Univ Islam Negeri Syarif Hidayatullah Jakarta. 2017;53(9):1689-99.

9. Kemenkes R. 5 M Dimasa Pandemi COVID 19 DI Indonesia. Pusat Analisis Determinan Kesehatan. 2021. Available from: http://www.padk.kemkes.go.id/article/read/2021/02/01/46/5-m-dimasapandemi-covid-19-di-indonesia.html

10. Notoatmodjo S. Pendidikan dan Perilaku Kesehatan. Jakarta: Rineka Cipta; 2010.

11. Amir, H., Batara, A. S., Sudarman, S., \& Asfar, A. (2020). Covid19 pandemic: management and global response. Jurnal Kesehatan Lingkungan, 12(1), 121-128. https://doi.org/10.20473/jkl.v12i1si.2020.12 1-128

12. Amir H, Agus AI, Bima MIM, As'ad I, Hafid MF, Ashar JR, Zainal AQ, Jihad A, Musda GH. Penerapan 3M dalam Mencegah Penularan Covid-19 di Desa Lonjoboko Kabupaten Gowa. IPM [Internet]. 2021Jun.26 [cited 2021Aug.13];1(1):1-4. Available from: https://ideapengabdianmasyarakat.ideajournal.id/index.php/ipm/article/view/1

13 Amir H. Nilai Islam dalam Praktik Keperawatan. Jurnal Penelitian Kesehatan Suara Forikes [Internet].2020 [cited 2021Aug.13];6-9. Available from:http://forikesejournal.com/index.php/SF/article/view/sf11nk302. 2020 